\title{
Adjustment of Local Regulation About Formation and Structure of Local Government
}

\author{
Dewi Kurniasih \\ Departemental of Government Science \\ Universitas Komputer Indonesia \\ Bandung, Indonesia \\ dekur010575@yahoo.com
}

\author{
Neng Suryanti Nengsih \\ Departemental of Government Science \\ Stisipol Raja Haji \\ Tanjung Pinang, Indonesia \\ suryatra@yahoo.com
}

\begin{abstract}
The government regulation amendment is always followed by adjustment of technique regulation implementation. Government Regulation Number 18 Year 2016 about Local Device has been ratified. Bandung Regency deftly attempting to adjust that Government Regulation with drafting a local regulation. Goals of this study is to determine the amount and type of local device as a implementor of government affairs as the mapping of Government affairs that have facilitated by Minister and the ministries / non-ministerial government agencies to provide guidance in the mapping based on the plan in accordance with the mapping information system of Government affairs as a workload determination of the local device. Method that used in this study is qualitative description. The results shown that the majority of the local device based on government affairs in Bandung Regency obtain high scores so as to have type $\mathbf{A}$.
\end{abstract}

Keywords—Local Government, Regulation, Formation,Structure.

\section{INTRODUCTION}

Post-Establishment of Act No. 23 of 2014 CONCERNING Local Government and Government Regulation No. 18 of 2016 as Substitute of Government Regulation No. 41 Year 2007 ABOUT Regional Unit, then it is only appropriate for Regional Regulation throughout Indonesia need to adjust the Organizational Structure of Governance based on the regulations, including the Government of Bandung regency.

Adjustments of the above provisions are based on the mapping of mandatory government affairs and government selection affairs. Mapping is then performed on the general variable and technical variables. This is done to obtain informations about the intensity of mandatory government affairs and the potency of government selection affairs as well as the workload of implementation of government affairs. Such information can be used to determine the composition and type of the regional unit.

The implementation of government affairs mapping is facilitated by the Governor as representative of the Central Government to coordinate the preparation and adjustment of the mapping plan. Ministry/agency then provides assistance and consultation to local government in mapping based on mapping plans and helps smooth mapping of government affairs by developing a government affairs mapping information system and determining local work load.

\section{RESEARCH METHOD}

This study raised concerns regarding adjustment of regional regulations on the organizational structure of work procedures in Bandung regency government. Researchers used descriptive research method. This research describes, summarizes various conditions, various situations or various variables arise in the community that became the problem, then pulled to the surface as a feature or a picture of the specific condition, situation or variables. The approach of this research is qualitative. Data expressed in the form of words or phrases and descriptions .

Selection of informants was based on the research subjects who understand the problem, have the data, and willing to share the data. Therefore, informant for the purposes of this study is the person or group of people that was deemed capable of providing general information about the organizational structure of work procedures in Bandung regency government.

Data collection techniques used in this study adjusted with the focus and purpose of the study, namely: Library Research and Field Research (Non-Participant Observation, Interviews, Documentation)

\section{RESULT AND DISCUSSION}

Regent, in the context of regional autonomy in Indonesia is a term for head of regencies. A regent is equal to mayor, the regional head to city area. Basically, regents have the duty and authority to lead the implementation of regional governance based on the policies set together with the regency Regional Parliament.

Regional Parliament based on Article 1 of Law No. 23 Year 2014 on Regional Government, states "Regional Parliament is the board of local people's representative that serves as a component of the Local Government". Furthermore, in Article 154 described the tasks and authorities of regencys Regional Parliament, they are: 1. Establish 
Regency Regulation together with the regent; 2. Discuss and approve the draft of local regulations regarding the Regional Government Budget of regencys proposed by the regents; 3 . Carry out supervision on the implementation of local regulations and Regional Government Budget of regencys; 4. Choose a regent; 5 . Propose the appointment and dismissal of regent to the Minister through the Governor as representative of the Central Government for approval of the appointment and dismissal; 6. Give opinion and consideration to regencys local government on international agreements in the Region; 7. Give approval on the international cooperation plan undertaken by the regency Regional Government; 8. Request accountability report of a regent of regency regional governance; 9. Approving the plan of cooperation with other areas or with third parties that burden the people and regions; 10. perform duties and other authority stipulated in the provisions of the legislation.

Regional Parliament as a legislative institution is a balance institution against the executive power, thus the state regulate the functions and duties of the Regional Parliament so that governance in an effective, transparent and accountable manner.

Secretariat area under the provisions of Article 213 of Law No. 23 of 2014, has a "duty to help regional heads in policymaking and administrative coordination of the performance of duties of the regional and administrative services".

Regency or city Regional Secretary referred to in Article 29 of Government Regulation No. 18 Year 2016 on Regional Unit lead by the regencies or cities Regional Seceretary and is responsible to the regent or mayor. Regency or city Regional Secretary has the task of helping the regent or mayor in policy formulation and administrative coordination of the implementation of the tasks of Regional Unit as well as administrative services.

Article 30 of Government Regulation No. 18 Year 2016 concerning the Region Unit, regency or city Regional Secretary is divided into three (3) types. Type of districts or city regional secretary consists of: 1 . Type A regency or city Regional Secretary to facilitate the implementation of the regional secretary functions of regencies or cities with a huge workload; 2. Type B regency or city Regional Secretariat to facilitate the implementation of the regional secretary functions of regencies or cities with moderate workload; and 3. Type $\mathrm{C}$ regency or city Regional Secretariat to facilitate the implementation of the regional secretary functions of regencies or cities with small workload.

Secretary of Regional Parliament under the provisions of Article 215 Paragraph 2 Act No. 23 of 2014 has the duty of: a. performing the administration of the secretariat; $b$. performing financial administration; c. supporting the implementation of the tasks and functions of Regional Parliament; and providing and coordinating expertise required by the Regional
Parliament in carrying out its functions according to the needs. Regional Inspectorate has the task to assist the regional head, guide and monitor the implementation of Government Affairs under the authority of Regional and co-administration by the Regional Unit as specified in Article 217 of Law No. 23 of 2014.

Secretary of Regional Parliament of regencies or cities are appointed and dismissed by the regent or mayor's decision on approval of the head or Regional Parliament of regencies or cities after consultation with the leaders of the faction. Secretariat of Regional Parliament of regencies or cities has the task of conducting secretariate and financial administration, to support the implementation of tasks and functions of Regional Parliament of regencies or cities, as well as providing and coordinating expertise required by the Regional Parliament of regencies or cities in performing its rights and functions as needed.

Secretariat of Regional Parliament of regencies or cities divided into three types which consist of: 1.Type A secretariat of Regional Parliament of regencies or cities to facilitate the implementation of the functions of the secretariat of Regional Parliament of regencies or cities with a huge workload; 2. Type B secretariat of Regional Parliament of regencies or cities to facilitate the implementation of the functions of the secretariat of Regional Parliament of regencies or cities with medium workload; and 3.Type $\mathrm{C}$ secretariat of Regional Parliament of regencies or cities to facilitate the implementation of the functions of the secretariat of Regional Parliament of regencies or cities with small workload.

According to Law No. 23 Year 2014 on Regional Government, "Regional Inspectorate has the task to assist the regional head to guide and monitor the implementation of Government Affairs under the authority of Regional and Assistance Task by the Region Unit". Regional Inspectorate in carrying out its duties is responsible to the head region through the Regional secretary.

Regional unit in the form of agency, structured as organizations responsible for Government Affairs under the authority of the Regions. This regional unit is classified into 3 types based on the workload that is taken care of. Type A agency was formed to accommodate Government Affairs under the authority of the Region with huge workload; furthermore, Type B agency was formed to accommodate Government Affairs under the authority of the Region with the medium workload; and for type $\mathrm{C}$ agency was formed to accomodate Government Affairs under the authority of Regions with small workloads.

Regional Comitee of Regency or City of Article 46 of Government Regulation No. 18 Year 2016 on Regional Unit, Regional Agency of regency/city is a support element of Goverment Affairs under the authority of regencies/cities. Regional Commitee of regencies/cities are led by the head 
agency of regencies or cities under and responsible to the regent or mayor through the secretaries of regencies or cities.

Regional Commitee of regency or city has the task of helping the regent or mayor in carrying out the supporting functions of Government Affairs under the authority of regencies or cities.

The formation of Regional committee of regencies/cities are based on the guidelines set by the Minister after obtaining written consideration from the minister who held the Government Affairs in the field of state apparatus.

Regional committee of regencies/cities is divided into three types. Type of Regional committee of regencies/cities consists of: 1. Type A secretariat of Regional Commitee of regencies or cities to facilitate the implementation of the functions of Regional Commitee of regencies or cities with a huge workload; 2. Type B secretariat of Regional Commitee of regencies or cities to facilitate the implementation of the functions of Regional Commitee of regencies or cities with medium workload; 3.Type $\mathrm{C}$ secretariat of Regional Commitee of regencies or cities to facilitate the implementation of the functions of Regional Commitee of regencies or cities with small workload.

In the case of based on the calculation of the variable values of a supporting function of Government Affairs does not qualify to form Regional Committee of regencies or cities itself, the supporting function of Government Affairs are merged with another committee.

Merging of supporting functions in of Government Affairs in 1 Regional Committee of regencies or cities based on grouping of supporting functions of Government Affairs with the following criteria: 1. Proximity supporting functions of Government Affairs; and / or 2. Linkages between the implementation of supporting functions of Government Affairs. Grouping of supporting functions of Government Affairs include: a. employment and education and training; and $\mathrm{b}$. planning and research and development.

Merging of supporting functions of Government Affairs is done at most two supporting functions of Government Affairs. Typology of regional commitees of regencies or cities which result of the merge of supporting functions of Government Affairs in accordance with the number of the fields of merge results.

In regional committee of regencies/cities, technical implementing unit of regional committee of regencies/cities may be established to carry out the technical operational and or specific technical support activities. Technical executing unit of regional committee of regencies or cities are divided into two classifications. Classification of technical operational units of regional committee of regencies or cities consist of: a. technical operational units of regional committee of regencies or cities type A to accommodate a large workload and b. technical and operational units of regional committee of regencies or cities type $\mathrm{B}$ to accommodate small workloads.

According to Article 1 of Law No. 23 of 2014 the District or called by any other name is part of the territory of regencies or cities, led by the head of district.

To improve coordination of governance, public service and community empowerment of village or district, then at the regencies/cities, sub-districts are formed. The formation of this organization different from other regional units, where give special attention to the provisions of the basic requirements, technical requirements, and administrative requirements. The organization is classified into two types: type A and type B with a basic consideration is the workload (Articles 221-223 of Law No. 23 of 2014).

Sub-district according to the Government Regulation No. 18 Year 2016 is the district unit that was formed to assist or carry out some tasks of the head of district. Sub-district of established by Regional regulation of regencies or cities guided by government regulation. Sub-district is led by Head of sub-district called the sub-district head and is responsible to the head of district.

Based on the potential of Bandung Regency associated with the provision by Government Regulation No. 18 Year 2016 on the Regional Unit particularly Article 6 about the typology criteria of regional unit, the composition of regional unit of Bandung regency can be analized as follows.

Scores of the Secretariat for Bandung Regency based on the variables are:

\begin{tabular}{|c|c|c|c|c|}
\hline Indicators & Value & Scale & Weight & Score \\
\hline $\begin{array}{c}\text { Total Population } \\
\text { (People) }\end{array}$ & $3,494,063$ & 1,000 & 10 & 100 \\
\hline $\begin{array}{l}\text { Area Range } \\
\text { (kilometer) }\end{array}$ & 1,768 & 1,000 & 5 & 50 \\
\hline $\begin{array}{c}\text { Number of } \\
\text { Regional } \\
\text { Government } \\
\text { Budget }\end{array}$ & $5,412,388,330,904$ & 1,000 & 5 & 50 \\
\hline $\begin{array}{c}\text { Number of } \\
\text { District }\end{array}$ & 31 & 1,000 & 15 & 150 \\
\hline $\begin{array}{c}\text { Number of Sub- } \\
\text { district }\end{array}$ & 280 & 800 & 5 & 40 \\
\hline $\begin{array}{l}\text { Number of } \\
\text { Regional Unit } \\
\text { Organization } \\
\text { (other than } \\
\text { district) }\end{array}$ & 72 & 1,000 & 20 & 200 \\
\hline $\begin{array}{l}\text { Number of } \\
\text { regional policy } \\
\text { (Regencies or } \\
\text { Cities regional } \\
\text { policy, Regents' } \\
\text { or Mayors' } \\
\text { Regulation and } \\
\text { regulation with } \\
\text { the head of } \\
\text { region) that are }\end{array}$ & 1,134 & 1,000 & 15 & 150 \\
\hline
\end{tabular}




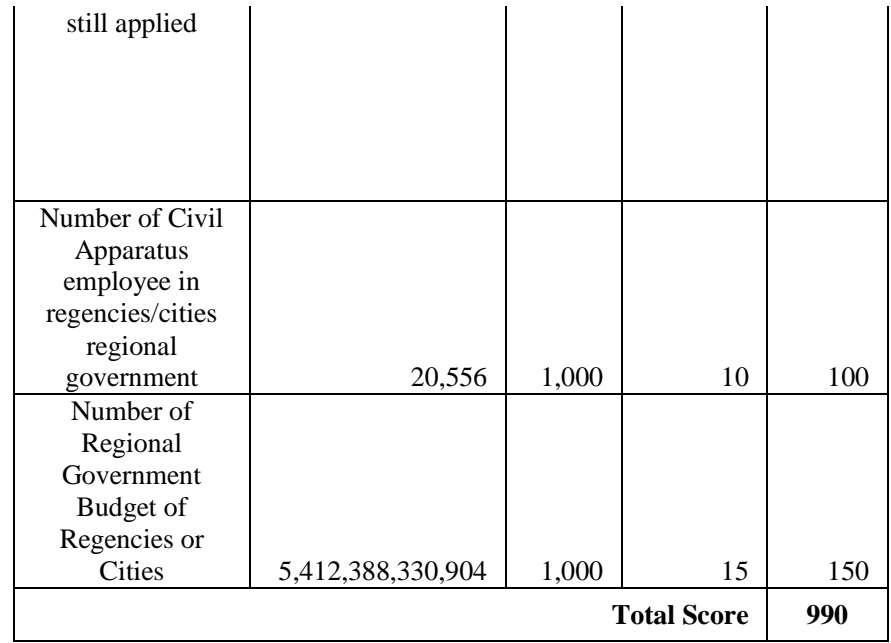

Based on the calculation above, then the Regional Secretarieate of Bandung regency was in type A.

Score achieved by Secretariate of Regional Parlement of Bandung based on the variable are:

\begin{tabular}{|c|r|r|r|r|}
\hline Indicators & \multicolumn{1}{|c|}{ Value } & Scale & Weight & Score \\
\hline $\begin{array}{c}\text { Total } \\
\text { Population } \\
\text { (People) }\end{array}$ & $3,494,063$ & 1,000 & 10 & 100 \\
\hline $\begin{array}{c}\text { Area Range } \\
\text { (kilometer) }\end{array}$ & 1,768 & 1,000 & 5 & 50 \\
\hline $\begin{array}{c}\text { Number of } \\
\text { Regional } \\
\text { Government } \\
\text { Budget }\end{array}$ & $5,412,388,330,904$ & 1,000 & 5 & 50 \\
\hline $\begin{array}{c}\text { Number of } \\
\text { Member of } \\
\text { Regional } \\
\text { Parliament }\end{array}$ & & & & \\
\hline $\begin{array}{c}\text { Number of } \\
\text { Regional }\end{array}$ & & & & \\
$\begin{array}{c}\text { Parliament } \\
\text { Faction } \\
\text { Daerah }\end{array}$ & 50 & 1,000 & & 40 \\
\hline \multicolumn{2}{|r|r|r|}{} \\
\hline
\end{tabular}

Based on the calculation above, then the Regional Parliament Secretarieate of Bandung regency was in type A.

Based on the analysis above, it was obtained that the amount and type of regional unit in the environment of Regional Government of Bandung Regency can be seen in the table below:

\begin{tabular}{|c|c|c|c|}
\hline No & Affairs & Score & Agency Type \\
\hline 1 & $\begin{array}{c}\text { ADMINISTRATION OF } \\
\text { POPULATION AND } \\
\text { CIVIL REGISTRY }\end{array}$ & 940 & A \\
\hline 2 & $\begin{array}{c}\text { ENERGY AND MINERAL } \\
\text { RESOURCES }\end{array}$ & 360 & $\begin{array}{c}\text { Non-separated } \\
\text { Regency or City } \\
\text { Agency (Field Level) }\end{array}$ \\
\hline 3 & INSPECTORATE & 890 & Tipe A \\
\hline 4 & ARCHIVAL & 790 & B \\
\hline 5 & CULTURE & 340 & $\begin{array}{c}\text { Non-separated } \\
\text { Regency or City }\end{array}$ \\
\hline
\end{tabular}

\begin{tabular}{|c|c|c|c|}
\hline & & & Agency (Field Level) \\
\hline 6 & FORESTRY & 250 & $\begin{array}{c}\text { Non-separated } \\
\text { Regency or City } \\
\text { Agency (Field Level) }\end{array}$ \\
\hline 7 & $\begin{array}{l}\text { MARINE AND } \\
\text { FISHERIES }\end{array}$ & 520 & $\mathrm{C}$ \\
\hline 8 & $\begin{array}{c}\text { STAFFING, EDUCATION } \\
\text { AND TRAINING }\end{array}$ & 960 & A \\
\hline 9 & YOUTH AND SPORTS & 1000 & A \\
\hline 10 & HEALTH & 920 & A \\
\hline 11 & $\begin{array}{l}\text { PEACE AND PUBLIC } \\
\text { ORDER AS WELL AS } \\
\text { PUBLIC PROTECTION }\end{array}$ & 880 & A \\
\hline 12 & MONETARY & 1000 & A \\
\hline 13 & $\begin{array}{l}\text { COMMUNICATION AND } \\
\text { INFORMATION }\end{array}$ & 870 & A \\
\hline 14 & $\begin{array}{c}\text { COOPERATIVE, SMALL } \\
\text { AND MEDIUM } \\
\text { BUSINESS } \\
\end{array}$ & 800 & B \\
\hline 15 & ENVIRONMENT & 910 & A \\
\hline 16 & FOOD & 980 & A \\
\hline 17 & TOURISM & 940 & A \\
\hline 18 & $\begin{array}{l}\text { PUBLIC WORKS AND } \\
\text { SPATIAL PLANNING }\end{array}$ & 806 & A \\
\hline 19 & $\begin{array}{l}\text { COMMUNITY AND } \\
\text { VILLAGE } \\
\text { DEVELOPMENT }\end{array}$ & 860 & A \\
\hline 20 & $\begin{array}{c}\text { WOMEN } \\
\text { EMPOWERMENT AND } \\
\text { CHILD PROTECTION }\end{array}$ & 770 & B \\
\hline 21 & CAPITAL INVESTMENT & 880 & A \\
\hline 22 & EDUCATION & 940 & A \\
\hline 23 & $\begin{array}{l}\text { RESEARCH AND } \\
\text { DEVELOPMENT }\end{array}$ & 710 & B \\
\hline 24 & $\begin{array}{c}\text { POPULATION } \\
\text { CONTROLLING AND } \\
\text { FAMILY PLANNING }\end{array}$ & 874 & A \\
\hline 25 & TRADING & 710 & B \\
\hline 26 & PLANNING & 988 & A \\
\hline 27 & $\begin{array}{l}\text { TRANSPORTATION (For } \\
\text { LAND Area) }\end{array}$ & 848 & A \\
\hline 28 & INDUSTRY & 600 & $\mathrm{C}$ \\
\hline 29 & LIBRARY & 410 & $\mathrm{C}$ \\
\hline 30 & CODING & 520 & $\mathrm{C}$ \\
\hline 31 & LAND & 590 & $\mathrm{C}$ \\
\hline 32 & AGRICULTURE & 952 & A \\
\hline 33 & $\begin{array}{c}\text { HOUSING AND } \\
\text { SETTLEMENT AREA }\end{array}$ & 770 & B \\
\hline 34 & $\begin{array}{c}\text { CIVIL SERVICE POLICE } \\
\text { UNIT }\end{array}$ & 880 & A \\
\hline 35 & $\begin{array}{c}\text { REGIONAL } \\
\text { SECRETARIAT }\end{array}$ & 990 & A \\
\hline 36 & $\begin{array}{c}\text { COUNCIL } \\
\text { SECRETARIAT }\end{array}$ & 920 & A \\
\hline 37 & SOCIAL & 976 & A \\
\hline 38 & STATISTIC & 750 & B \\
\hline 39 & WORK FORCE & 820 & A \\
\hline
\end{tabular}




\begin{tabular}{|l|l|l|c|}
40 & TRANSMIGRATION & 254 & $\begin{array}{c}\text { Non-separated } \\
\text { Regency or City } \\
\text { Agency (Field Level) }\end{array}$ \\
\hline
\end{tabular}

\section{CONCLUSION}

Based on the analysis of regional unit above, we conclude the following: 1. Government affairs of Public Works and Spatial Planning, which performed by the Public Works and Spatial Planning Department type A can be added with 2 fields. 2. Government affairs of Agriculture Department performed by Agriculture Department type A can be added with 2 fields; 3 . Government affairs of finance that performed by Local Finance Department Type A, can be added with 2 fields; 4. Government affairs of communication and information field, coding field, and statistics field that performed by the Department of Communications and Information Technology, Coding and Statistics type A, can be added with one field. 5. The Sub-district entrance as the District Unit. 6. Publish the Regent Decree regarding the position, organizational structure, duties and functions, as well as the working procedures of the Region consists of regional secretariat, Regional Parliament secretariate, Inspectorate, Agencies Boards, and District. 7. Set a separate Regent Decree on the positions, organizational structure, duties and functions, as well as the working procedures of the Regional Disaster Management Agency as other support functions .8. Further provisions on the status, organizational structure, duties and functions, as well as the working procedures of the National Unity and Politics organized and determined later through separate legislation after legislation regarding the implementation of public government affairs promulgated.

\section{ACKNOWLEDGEMENT}

The researchers expresses his highest gratitude to Allah Subhanahu wata'ala for blessing, love, opportunity, health and mercy to complete this article. Thank to Bandung Regent, our Rector and family. Finally, I would like to thank everybody who was important to the succesful realization of this research.

\section{REFERENCES}

[1] Brunsson, Nils. 2009. Reform As Routine: Organizational Change And Stability in The Modern World. New York:Oxford University Press.

[2] Damanik Khairul Ikhwan, dkk. 2010. Otonomi Daerah, Etnonasionalisme, dan Masa Depan Indonesia, Berapa Persen lagi Tanah dan Air Nusantara Milik Rakyat?. Jakarta:Yayasan Pustaka Obor Indonesia.

[3] Dwiyanto, Agus. 2005. Mewujudkan Good Governance Melalui Pelayanan Publik. Yogyakarta: Gadjah Mada University Press.

[4] Yunus, Muhammad. 2014. Structuring Policy of the Organizational Structure on Regional Devices in Makassar, Indonesia. International Journal of Science and Research (IJSR). ISSN (Online):2319-7064. (page:594-600).

[5] The International Journal of Social Sciences. December 2014 Volume 29th. Number 1. ISSN 2305-4557. 